ENCYCLOPEDDE Encyclopédie berbère

BERBERE

28-29 | 2008

28-29 | Kirtēsii - Lutte

\title{
Leucoe Aethiopes
}

\section{J. Desanges}

\section{OpenEdition}

Journals

Édition électronique

URL : http://journals.openedition.org/encyclopedieberbere/326

DOI : 10.4000/encyclopedieberbere.326

ISSN : 2262-7197

\section{Éditeur}

Peeters Publishers

\section{Édition imprimée}

Date de publication : 1 janvier 2008

Pagination : 4366

ISBN : 2-7449-0707-4

ISSN : 1015-7344

\section{Référence électronique}

J. Desanges, «Leucoe Aethiopes », Encyclopédie berbère [En ligne], 28-29 | 2008, document L15, mis en ligne le 01 juin 2013, consulté le 25 septembre 2020. URL : http://journals.openedition.org/ encyclopedieberbere/326 ; DOI : https://doi.org/10.4000/encyclopedieberbere.326

Ce document a été généré automatiquement le 25 septembre 2020

(C) Tous droits réservés 


\section{Leucoe Aethiopes}

\section{J. Desanges}

1 L'ethnonyme grec signifie "Éthiopiens blancs». Pomponius Méla (I, 23) situe les Leucoaethiopes " au-dessus des terres baignées par la mer Libyque », entre les Libyes Aegyptii* d'une part et les Gétules* de l'autre, ces trois peuples étant séparés par une bande de terre désertique de populations plus méridionales (de l'est à l'ouest: les Garamantes*, les Augiles [cf. Augila*], les Troglodytes* et les Atlantes*). Pline l'Ancien $(\mathrm{V}, 43)$ intercale au contraire la zone désertique intermédiaire entre les Gétules au nord et les Libyes Aegyptii et Leucoe Aethiopes au sud, ces derniers peuples étant bordés encore plus au sud par des populations éthiopiennes (Nigrites*, Pharusii* et Perorsi*). Il est possible que les témoignages de Méla et de Pline proviennent d'une source commune différemment interprétée. Ptolémée (G., IV, 6, 6, Müller : 745) situe, quant à lui, les Leukaethiopes sous le mont Rhysadion, non loin des Perorsi dont les sépare le «Purrhon Pedion », c'est-à-dire la «Plaine Rouge », ou plutôt la «Plaine au Feu », cf. Périple d'Hannon, 13 (écho dans Pline, II, 237), précision qui nous conduit dans le Sud marocain, peut-être du côté du Sous.

2 St. Gsell (H.A.A.N, I : 299) pense que les Leucoe Aethiopes sont des Éthiopiens qui se peignent en blanc. Il s'agit plutôt, croyons-nous, d'un peuple métissé, comme les Mélanogétules*, dont il est difficile de croire que ce sont des Gétules qui se peignent en noir.

3 Voir « Aethiopes » $(\underline{E B}$ II, A71).

INDEX

Mots-clés : Antiquité, Libye, Population/peuplement, Tribu(s) 